\title{
The effect of secondary school students' writing tendencies and self-efficacy on writing attitudes: A structural equation modeling
}

\author{
Faruk Polatcan ${ }^{\text {* }}$ (D), Nurullah Şahin \\ ${ }^{a}$ Sinop University, Sinop, Turkey \\ ${ }^{b}$ A ̆̆rı İbrahim Çeçen University, Ağrl, Turkey
}

\section{APA Citation:}

Polatcan, F, \& Şahin, N. (2019). The effect of secondary school students' writing tendencies and self-efficacy on writing attitudes: A structural equation modeling. Journal of Language and Linguistic Studies, 15(2), 739-753.

Submission Date: 08 /02/2019

Acceptance Date: 17/05/2019

\begin{abstract}
The aim of this study was to determine the effect of secondary school students' writing tendency, writing selfefficacy and writing attitude variables and how these variables predict each other through structural equation modeling. For this purpose, the relational screening model was used and the study was carried out in academic year 2018-2019 on a total of 290 students;153 (52.8\%) were females and 137 (47.2\%) were males studying in 4 different secondary schools in Erzurum. Twenty of the students were in the 5th grade, 30 were in the 6th grade, 104 were in the 7th grade and 122 were in the 8th grade. In the study, the writing disposition scale developed by Piazza and Siebert (2008) and adapted to Turkish by Iseri \& Ünal (2010); writing attitude scale developed by Can \& Topçuoğlu Ünal (2017); and writing self-efficacy scale developed by Şengül (2013) were applied to secondary school students. After their validity and reliability were ensured, the data were analyzed. As a result of the study, it was determined that writing tendency had a positive effect on writing attitude, and despite writing self-efficacy positively affected writing attitude, it did not affect it significantly statistically.
\end{abstract}

(C) 2019 JLLS and the Authors - Published by JLLS.

Keywords: Writing tendency; writing self-efficacy; writing attitude

\section{Introduction}

Language, the most perfect and complex way of communication between society and individuals, is the general name of the toolsets that provide communication between living creatures and living creatures; living creatures and things that can be counted as partly living (Machines) and living and nonliving things (physicochemist world) (Gemalmaz, 2010, p. 53). The basic elements of this advanced system known as language are listening, reading, speaking and writing skills, which are commonly called as the four skills of language in the literature. By help of these four skills, language becomes the most important part of the network of communication in society. The development of these four skills is necessary for both foreigners who want to learn that language and for the users of that language (Şahin, 2012, p. 1).

\footnotetext{
${ }^{*}$ Corresponding author. Tel.: +90-368-271-5527

E-mail address: farukpolatcan @gmail.com
} 
The four basic skills of the language are not in a structure that develops independently and needs to be evaluated separately but on the contrary, they complement each other and their development processes must be evaluated together. In the language training process, all skills are different, but all of them are equally important. In terms of efficiency of teaching Turkish, basic skills areas need to be developed in an integrated manner with adequate, effective and appropriate activities (İşeri \& Ünal, 2010, p. 106). Therefore, training processes for language skills should be planned well.

The writing skills, which is learnt after other language skills, constitute the narrative dimension of the language together with the speaking skill. Writing is not a mechanical process; on the contrary, it is a critical thinking process in terms of being a skill in the areas of cognitive, social and affective. This process includes learning, understanding, application and synthesis of new knowledge (Defazio, Jones, Tennant \& Hook, 2010; Demirel, 1999; Schultz \& Fecho, 2000; White \& Bruning, 2005).

There are some important factors affecting the success of writing practice which contribute to the development of students' mental, language, social and independence skills (Güneş, 2007, p. 162). The students' beliefs such as writing tendencies, writing attitudes, and writing self-efficacy are the leading factors. Writing is the most difficult language skill as it requires high level of thinking abilities. Having a complex nature, writing provides individuals with such skills as observation power, ability to analyze, ability to perceive, rich vocabulary, etc. when cultivated properly. However, there are many factors in play to succeed in writing. Emerging in cognitive, affective and psychomotor dimensions, these factors have a direct impact on writing to achieve its goal. Writing disposition, writing attitude and writing selfefficacy of students are primary factors in this regard. It is considered important to identify writing disposition, writing attitude and perceived writing self-efficacy of students, and to develop them in a positive direction for achieving the desired goal in writing. Having a closer look at writing disposition, writing attitude and perceived writing self efficacy provides better understanding of the subject.

\subsection{Literature review}

In order to improve writing skills and to ensure the success of writing activities, it is important to determine the students' tendency towards writing and to develop them in a positive way. Because this tendency towards writing is a strong motivation source (Bruning \& Horn, 2000).

The word "tendency" synonymous with the words Meyil \& Temayül is defined as follows intending to love, want or do something in Turkish dictionary (Turkish Language Society, 2011, p. 605). The concept of tendency in many different areas such as politics, education, art and psychology can be understood as the internal tendency of a person to a certain view, understanding, behavior and belief. The tendency, defined as the frequency of action according to some is guided by the individual's values, beliefs, attitudes (researchers (Buss \& Craik, 1983; Katz, 1993; Almerico, Johnston, Henriott \& Shapiro, 2011). According to this, tendency arises at the stage of the transformation of these beliefs and attitudes into behavior. Therefore, it can be considered that the tendency plays a triggering role in the process of realizing an individual behavior (Baştuğ, 2015, p. 75).

Hence, the writing tendency means, wanting to write, liking to write, having tolerance to any difficulties in the process of writing, and to become motivated to overcome any difficulties in writing (Baştuğ, 2015; Piazza \& Siebert, 2008). Writing tendency is a concept divided into different dimensions by different scientists. For example, McClenny examined the writing tendency in three dimensions. These dimensions are: the cognitive dimension which consists of students' knowledge and skills; motivation, patience, self-efficacy, factors affecting the student's willingness to participate in any event; and, finally, the social context dimension which is formed through the combination / intersection of cognition and emotion dimension (McClenny, 2010). 
On the other hand, Piazza and Siebert divided the writing tendency into three different dimensions. These are: confidence dimension expressing the individual's confidence in himself and his ability to write; determination dimension expressing the individuals' will to constantly wanting to write; and finally, the dedication of the individual to write and him wanting to write non-stop, the dimension of passion (Piazza \& Siebert, 2008). Baş and Şahin (2013) suggested that gender, educational level of parents and family income variables affect writing disposition in primary school students. On the other hand, Uçgun (2014) found that there was no significant relationship between students' writing disposition and educational level of their parents. Baştuğ (2015) stressed that writing disposition and writing attitude affect writing achievement in a significantly positive way while writing attitude and disposition affect writer's block in a significantly negative way, and writer's block has a significantly negative impact on writing achievement. According to Berk and Ünal (2017), writing disposition is a significant predictor of writing apprehension.

Self-efficacy is defined as situational awareness (Bandura, 1982) about the individual's confidence in his / her ability to successfully implement the plan and to plan the steps necessary to display a certain performance in a particular subject. According to Snyder and Lopez (2002), although self-efficacy is not a skill that can be observed or perceived, it can be defined as the inner belief that the individual has for his / her answer to the question of "what I can do in this situation". Based on these definitions, writing self-efficacy refers to the individual's perception of his / her own level of writing skill. Hidi \& Boscolo (2006) describe the self-efficacy of writing as a personal perception of one's ability to form texts; while Pajares, Hartley \& Valiante (2001) defined it as that students' beliefs about whether they can write articles that can be appropriate to their academic level.

The higher the self-efficacy that can be at different levels, strengths and prevalence in each person, the higher the strength of struggle, the sense of patience and the motivation. In other words, self-efficacy has a significant impact on the success of individuals. Thus, the writing skill of individuals is a condition associated with their ability to be successful in terms of writing performance and a positive self-efficacy perception (Şengül, 2013, p. 82). The student with the writing self-efficacy believes that he will succeed before he starts writing and it is easy for him to continue the behavior as he / she starts with a high level of motivation (Demir, 2013, p. 92). It is not difficult to predict that a student with a lower self-efficacy is less involved in writing-related jobs or tasks and has given up more quickly in the face of the difficulties they face (Pajares, 2007). Demir (2013) indicated that students with high writing selfefficacy also usually have good creative writing skills. Şengül (2013) and Büyükikiz (2012) developed a valid and reliable scale to measure writing self-efficacy.

The concept of attitude is a subject, which has been emphasized in many disciplines, especially in psychology. Attitude is an emotional readiness or tendency of an individual to accept or reject as a particular person, a group, an institution, or a thought (Özgüven, 1994, p. 336).

The attitudes people gain during their lives continue for a certain period of time. Thus, after gaining an attitude, attitude cannot be considered as neutral against the situation or the object it has been formed towards. Attitudes that are very difficult to change once they have been gained are considered to be the dispositional tendency of the individual and have a measurable property (Tavşancıl, 2010; Silah, 2000; Sözer, 1996; Susar Kırmızı \& Beydemir, 2012).

In the light of this information Graham, Berninger and Fan (2007) consider writing attitude as one of the motivating factors in writing and describe it as a process which includes an effective writing tendency. Attitudes are critical in the education of language skills, especially in the education of reading and writing skills. What makes the writing attitude important is that it is an important predictor, which has a direct effect on students' writing achievement. Therefore, developing positive attitudes towards writing in students should be one of the primary objectives of writing activities. Because positive 
attitudes create an opportunity for students to increase their writing success, to make more efforts to write and to write more often; negative attitudes will cause students to lose their writing success, avoid effort to write, and avoid writing as much as possible (Baş \& Şahin, 2013; Baştuğ, 2015; Graham, Berninger and Fan, 2007; Karatay, 2011). As a result, students' positive or negative experiences in writing in the past cause students to gain positive or negative attitudes towards writing. The attitudes gained as a factor directly affect the students' writing success. Writing activity has a positive impact on the attitude towards writing (Susar Kırmız1, 2009; Susar Kırmızı and Beydemir, 2012). In parallel with this finding, it was reported that prospective Turkish teachers attached greater importance to writing thanks to the Lecturing Techniques II: Writing Training course they received (Göçer, 2016).

\subsection{Research questions}

In this study, the model of the study which examined the effects of writing tendencies and writing self-efficacy on writing attitude is presented in Figure 1.

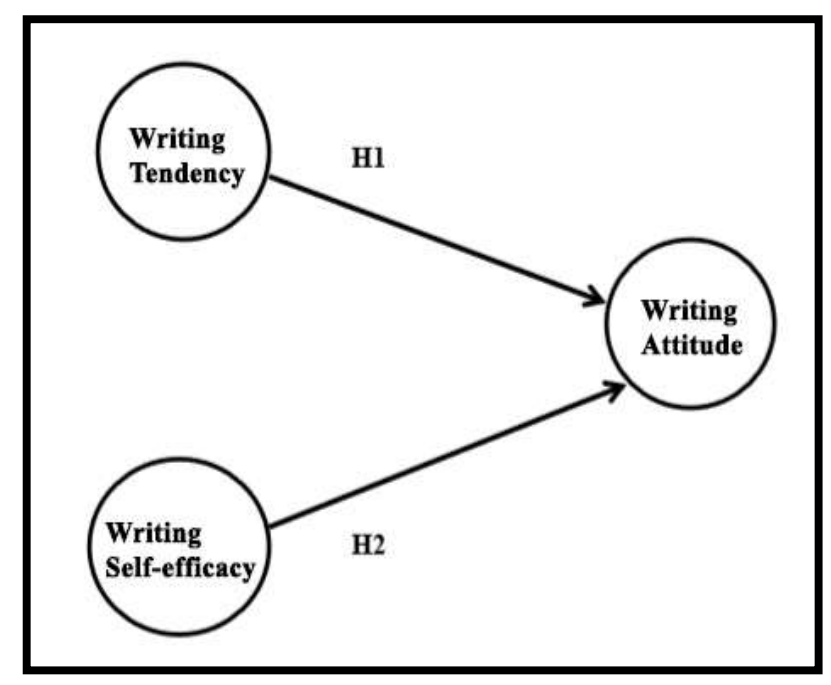

Figure 1. Hipotez Model

In the framework of the model in Figure 1, the aim of the research is to determine the effect level of secondary school students' writing tendency, writing self-efficacy and writing attitude variables and how the variables predict each other. The hypotheses proposed for testing are presented below:

H1: Writing tendency positively and significantly predicts the writing attitude.

$\mathrm{H} 2$ : Writing self-efficacy positively and significantly predicts writing attitude.

\section{Method}

In the research, using the relational screening model, it was aimed to determine the writing tendencies of the 5th, 6th, 7th and 8th graders, the effect of writing self-efficacy on writing attitudes, how the variables predict each other and the effect level of the variables. In the relational screening model, it is aimed to determine the presence and / or degree of coexistence between two and more variables (Karasar, 2012, p. 81). The theoretical model (Figure 1) formed as a result of the literature review and the relations between the variables in the theoretical model were tested by Structural Equation Model (SEM). SEM is used to investigate the linear structural relationships between all the variables in the model (Çelik \& Y1lmaz, 2013, p. 5). 


\subsection{Sample / Participants}

The working group was selected according to the easy-to-reach sampling method considering the economy and easy accessibility. The study was carried out in academic year 2018-2019 on 290 students; $153(52.8 \%)$ were females and $137(47.2 \%)$ were males studying in 4 different secondary schools in Erzurum, Turkey. Twenty of the students were in the 5th grade, 30 were in the 6th grade, 104 were in the 7 th grade and 122 were in the 8 th grade.

\subsection{Instrument( $s)$}

\subsubsection{Writing Disposition Scale}

The aim of the Writing Disposition Scale developed by Piazza and Siebert (2008) is to measure the affective attitudes of the students about the writing. The first form of the scale consists of 93 items consisting of 3 factors. In the last version of the scale developed by Piazza and Siebert (2008); a scale consisting of a total of 11 items with 3 factors, 3 of which is trust, 4 of which is continuity and 4 of which is passion was obtained. Passion factor of scale Cronbach Alpha reliability coefficient was 0.91, confidence sub-factor Cronbach Alphareliability coefficient was 0.80 , continuity sub-factor Cronbach Alpha reliability coefficient was 0.74 and overall scale Cronbach Alpha reliability coefficient was found to be 0.89 (Piazza \& Siebert, 2008).

In the study, the version adapted to Turkish by İşeri \& Ünal(2010) was used. In the process of Turkish adaptation, 93 items were used. The scale was prepared in 5-Likert type and consisted of "totally do not agree" (1), "do not agree" (2), "not sure" (3), "agree" (4), "totally agree" (5). To determine the construct validity of the scale Exploratory Factor Analysis (EFA) and Confirmatory Factor Analysis (CFA) were carried out. According to the result of EFA, it was found that it consists of 21 items and the 3 following factors: "passion", "confidence" and "continuity". In the study, as a result of the EFA performed, it can be said that the fit indices of the model are at the level of good fit ( $\chi 2: 1.243$, sd: 128, RMSEA: 0.008 , NFI: 0.99, CFI: 0.99, GFI: 0.99, AGFI: 0.99). To determine the reliability of the scale Standardized Regression weights were used. Reliability for Passion sub-dimension was 0.81 , reliability for confidence sub-dimension was 0.65 , and the reliability for the continuity sub dimension was calculated as 0.54 .

The reliability and validity study of the writing tendency scale was repeated for this research. The analyzes are as:

Confirmatory Factor Analysis: CFA results to determine whether the factor structures in the original writing tendency scale are confirmed within the framework of this research are given in Figure 2. 


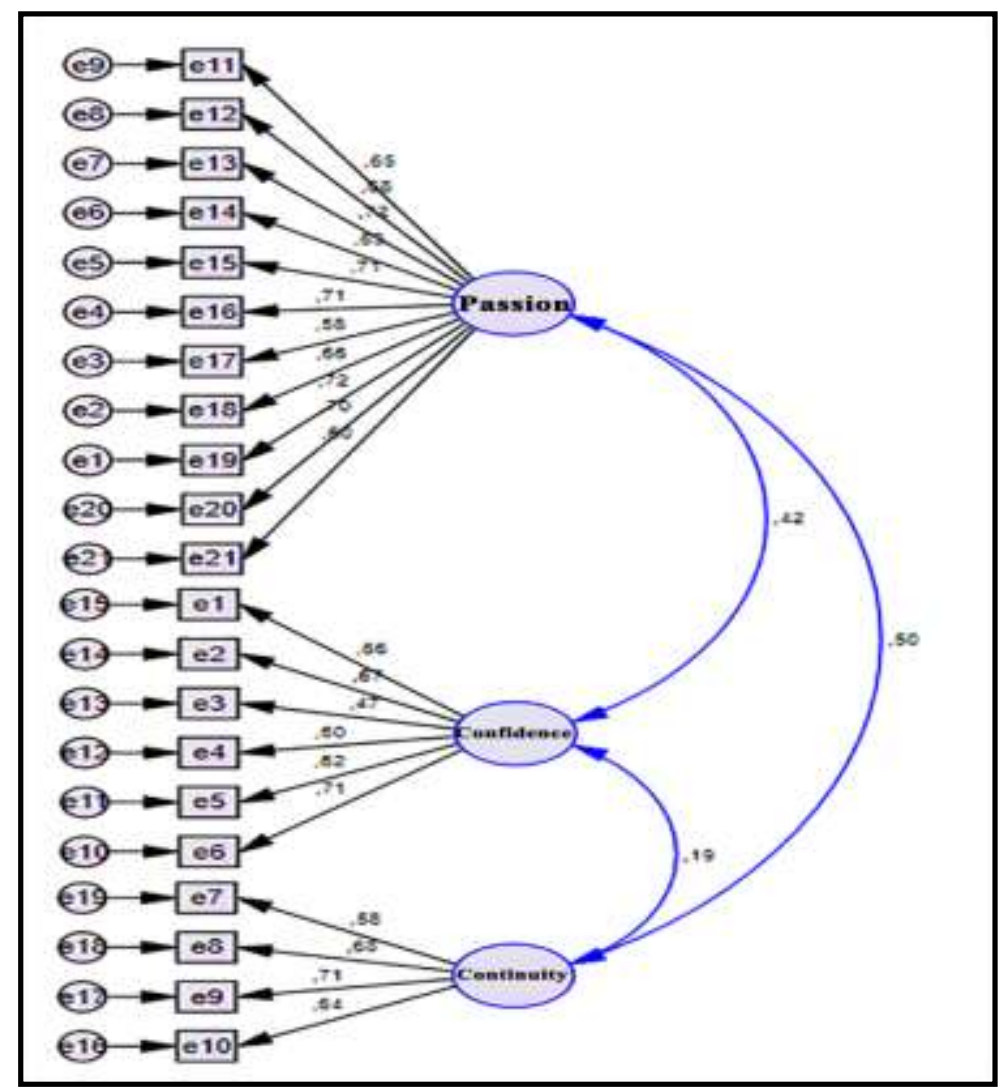

Figure 2. CFA on writing tendency scale

The goodness of fit values obtained in the CFA performed on the writing tendency scale were found to be: $(\chi 2: 2,313$, sd: 186 , RMSEA: 0,06, NFI: 0,82, CFI: 0,89, GFI: 0,86, AGFI: 0,83). According to the obtained data, it can be said that the fit goodness index of the model of writing tendency scale is at an acceptable level.

Reliability Analysis: To determine the reliability of the writing tendency scale Cronbach Alpha internal consistency coefficient was calculated. According to this, the following values were obtained: 0.89 for the passion sub-factor, 0.78 for the confidence sub-factor, 0.74 for the continuity sub-factor and 0.88 for the overall scale. According to these values, the measurement tool is considered to be reliable.

\subsubsection{Writing self-efficacy scale}

The aim of the "Writing Self-Efficacy Scale" developed by Şengül (2013) is to develop a scale to evaluate the writing self-efficacy of secondary school students. The scale was prepared in 5-Likert type and consisted of "totally do not agree", "do not agree ", "not sure", "agree", "totally agree" In order to determine the construct validity of the scale, only EFA was performed. As a result of EFA, it was determined that 40 of the 30 items are positive, 10 of them are negative, and that it consists of a fourfactor structure including writing skill awareness, writing psychology, personal progress and general progress . Since CFA was not performed, there is no data for good fit indexes of the model. In order to determine the reliability of the scale, Cronbach Alpha internal consistency coefficient and Guttman Split-Half Coefficient and Spearman-Brown Coefficient were also calculated. Cronbach Alpha internal consistency coefficient was found to be 0.92 for the scale, 0.91 for the writing skill awareness factor, 0.86 for the writing psychology factor, and 0.88 for the personal progress factor. Guttman Split-Half Coefficient coefficient was found to be 0.84 , Spearman-Brown Coefficient coefficient was found to be 0.84. According to these coefficients, the items in the scale can be said to be consistent with each other. 
The reliability and validity study of the reading self-efficacy scale was conducted for this study. The analyzes are as:

Confirmatory Factor Analysis: Figure 3 shows the results of the CFA performed to determine whether the factor structures in the original form of the reading self-efficacy scale are confirmed within the framework of this study.

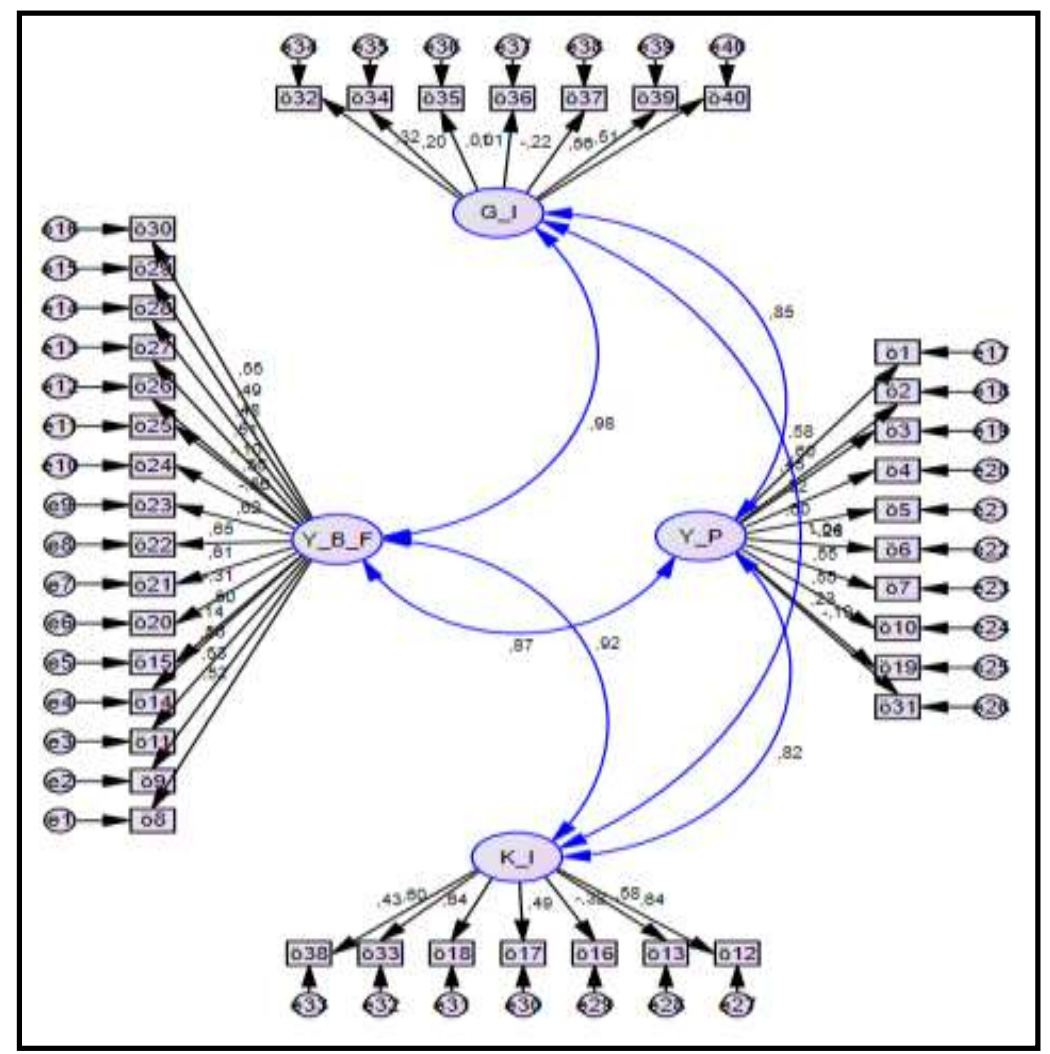

Figure 3. CFA on reading self-efficacy scale

It was observed that the goodness of fit values obtained from the CFA performed for the self-efficacy scale for reading was ( $\chi^{2}: 2,05$, sd: 734, RMSEA: 0,06, CFI: 0,73, GFI: 0,77, AGFI: 0,74). According to the obtained data, it can be said that the fit goodness indices of the model related to reading selfefficacy scale are at an acceptable level.

Reliability Analysis: The Cronbach Alpha internal consistency coefficient was calculated to determine the reliability of the reading attitude scale. According to this, the following values were obtained; 0.81 for the overall scale, 0.75 for the "writing skill awareness" factor, 0.72 for the "writing psychology" factor, 0.73 for the "personal progress" factor and 0.71 for the "general progress" factor. According to these values, it can be said that the measurement tool is reliable.

\subsubsection{Writing attitude scale}

The aim of the Writing Attitude Scale developed by Can and Topçuoğlu Ünal (2017) is to determine the writing attitudes of secondary school students. The scale was prepared in 5-Likert type and consisted of "totally do not agree", "do not agree", "not sure", "agree", "totally agree" for the positive items. The negative items were reversed in the SPSS package program. In order to determine the construct validity of the scale, EFA and CFA were conducted. As a result of EFA, it can be understood that the scale consists of 23 items, and has a 3 factor structure including "interest", "perception" and "contribution". As a result of the DFA, the fit indices of the model were found to be at an acceptable level ( $\chi 2: 497.54$; sd: 226; RMSA: 0.09, GFI: 0.75, SRMR: 0.09, CFI: 0.79, NNFI: 0.76, RMR: 0.07). To determine the reliability of the scale Cronbach Alpha internal consistency coefficient was calculated. This coefficient 
was found to be 0.89 for the overall scale, 0.84 for the interest factor, 0.70 for the perception factor and 0.72 for the contribution factor.

For this study, the reliability and validity of the reading attitude scale were repeated. The analyzes are as follows: The analyzes are as:

Confirmatory Factor Analysis: The results of the CFA to determine whether the factor structures in the original reading of the reading attitude scale are confirmed within the framework of this study are given in Figure 4.

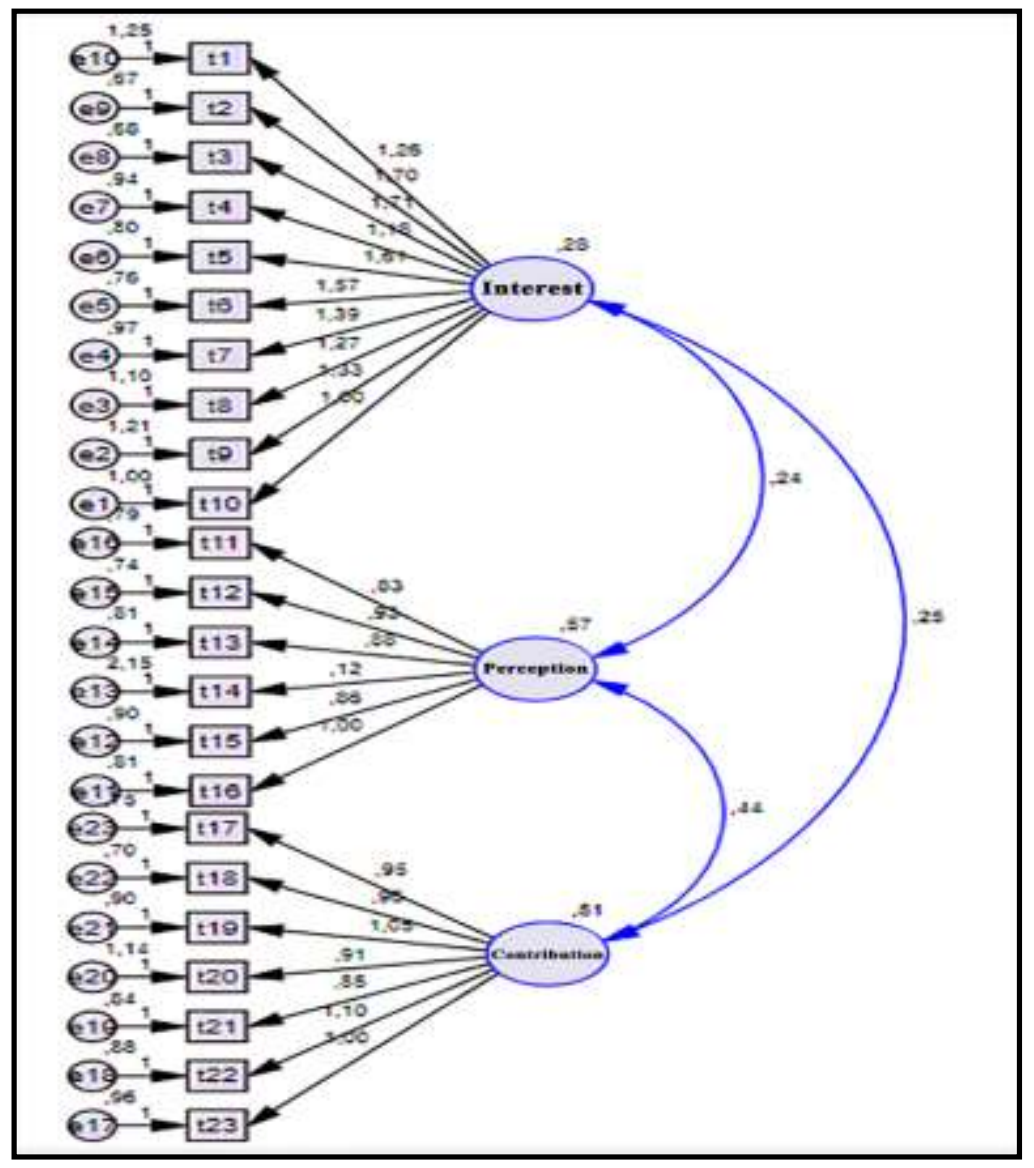

Figure 4. CFA on the reading attitude scale

The goodness of fit achieved from the result of the CFA on the reading attitude scale was found to be ( $\chi 2$ : 2,51, sd: 227, RMSEA: 0.07, NFI: 0.75, CFI: 0.83, GFI: 0.84, AGFI: 0.80). According to the obtained data, it can be said that the goodness of fit index of the model of reading attitude scale is at an acceptable level.

Reliability Analysis: The Cronbach Alpha internal consistency coefficient was calculated to determine the reliability of the reading attitude scale. This coefficient is 0.89 for the overall scale, 0.85 for "interest" factor, 0.73 for the "perception" factor and 0.79 for the "contribution" factor. According to these values, it can be said that the measurement tool is reliable.

\subsection{Data collection and analysis}

SPSS 22 and AMOS 24 were used to analyze the data. To examine the relationship between writing tendency, writing self-efficacy and writing attitudes Structural Equation Modeling used. For the compatibility of the data obtained in the analysis $\chi^{2}$, RMSEA, CFI, GFI and AGFI compliance indices were examined. CFI, GFI and AGFI values are close to 1 and RMSEA values are below 0.08 and this can be considered as an acceptable compliance (Karagöz, 2016, p. 969-972, 992). 


\section{Results}

In this study, the effects of writing tendency and writing attitudes on the writing self-efficacy of secondary school students were investigated. For this purpose, first of all, correlation analysis was conducted to test the relationship between the writing attitude of the research and the predictive tendency of the research and the writing self-efficacy in the process of analyzing the data related to the effect of "writing tendency" and "writing self-efficacy" on "writing attitude". The relationships between variables are given in Table 1.

Table 1. Correlation Relationships Between Variables

\begin{tabular}{crrrrrrrrrr}
\hline & Co & $\mathbf{C}$ & $\mathbf{P}$ & $\mathbf{I}$ & $\mathbf{P e}$ & $\mathbf{C o n}$ & $\mathbf{W S A}$ & $\mathbf{W P}$ & $\mathbf{P P}$ & $\mathbf{G P}$ \\
\hline $\mathbf{C o}$ & 1 & & & & & & & & \\
$\mathbf{C}$ & $0.16^{* *}$ & 1 & & & & & & & \\
$\mathbf{P}$ & $0.36^{* *}$ & $0.42^{* *}$ & 1 & & & & & & \\
$\mathbf{I}$ & $0.42^{* *}$ & $0.44^{* *}$ & $0.77^{* *}$ & 1 & & & & & \\
$\mathbf{P e}$ & $0.40^{* *}$ & $0.13^{*}$ & $0.34^{* *}$ & $0.47^{* *}$ & 1 & & & & \\
$\mathbf{C o n}$ & $0.47^{* *}$ & $0.24^{* *}$ & $0.49^{* *}$ & $0.57^{* *}$ & $0.62^{* *}$ & 1 & & & \\
$\mathbf{W S A}$ & $0.42^{* *}$ & $0.20^{* *}$ & $0.37^{* *}$ & $0.45^{* *}$ & $0.37^{* *}$ & $0.46^{* *}$ & 1 & & \\
$\mathbf{W P}$ & $0.38^{* *}$ & $0.28^{* *}$ & $0.44^{* *}$ & $0.46^{* *}$ & $0.31^{* *}$ & $0.46^{* *}$ & $0.56^{* *}$ & 1 & \\
$\mathbf{P P}$ & $0.33^{* *}$ & $0.23^{* *}$ & $0.36^{* *}$ & $0.41^{* *}$ & $0.32^{* *}$ & $0.46^{* *}$ & $0.64^{* *}$ & $0.51^{* *}$ & & \\
$\mathbf{G P}$ & $0.30^{* *}$ & 0.08 & $0.30^{* *}$ & $0.38^{* *}$ & $0.38^{* *}$ & $0.36^{* *}$ & $0.46^{* *}$ & $0.32^{* *}$ & $0.45^{* *}$ & 1 \\
\hline
\end{tabular}

$* 0.05, * * 0.01$

Note: Co: Confidence, C: Continuity, P: Passion, I: Interest, Pe: Perception, Con: Contribution, WSA: Writing Skill Awareness, WP: Writing Psychology, PP: Personal Progress, GP: General Progress.

In Table 1, there is a positive but low relationship between the confidence dimension and continuity dimension; while there is a positive and moderate relationship between confidence dimension and other dimensions. While the continuity dimension has positive and moderate relationship with confidence, passion and interest dimension, it has positive and weak relationship with other dimensions. In the study, there is a positive and strong relationship only between interest dimension and passion dimension. Last but not least, it can be said that there is a positive and moderate relationship between passion, interest, perception, contribution, writing skill awareness, writing psychology, personal progress and general progress dimensions. In the values between variables, 0-0.29 signifies a weak-level relationship, 0.300.69 signifies an moderate-level relationship, and 0.70-1.00 signifies a strong-level relationship (Büyüköztürk, 2006).

After examining the relationships between the predictive and predicted variables of the research, the predictive effect of the "writing attitude" variable on the "writing tendency" and "writing self-efficacy" variable was tested through track analysis. The model tested is shown in Figure 5. 


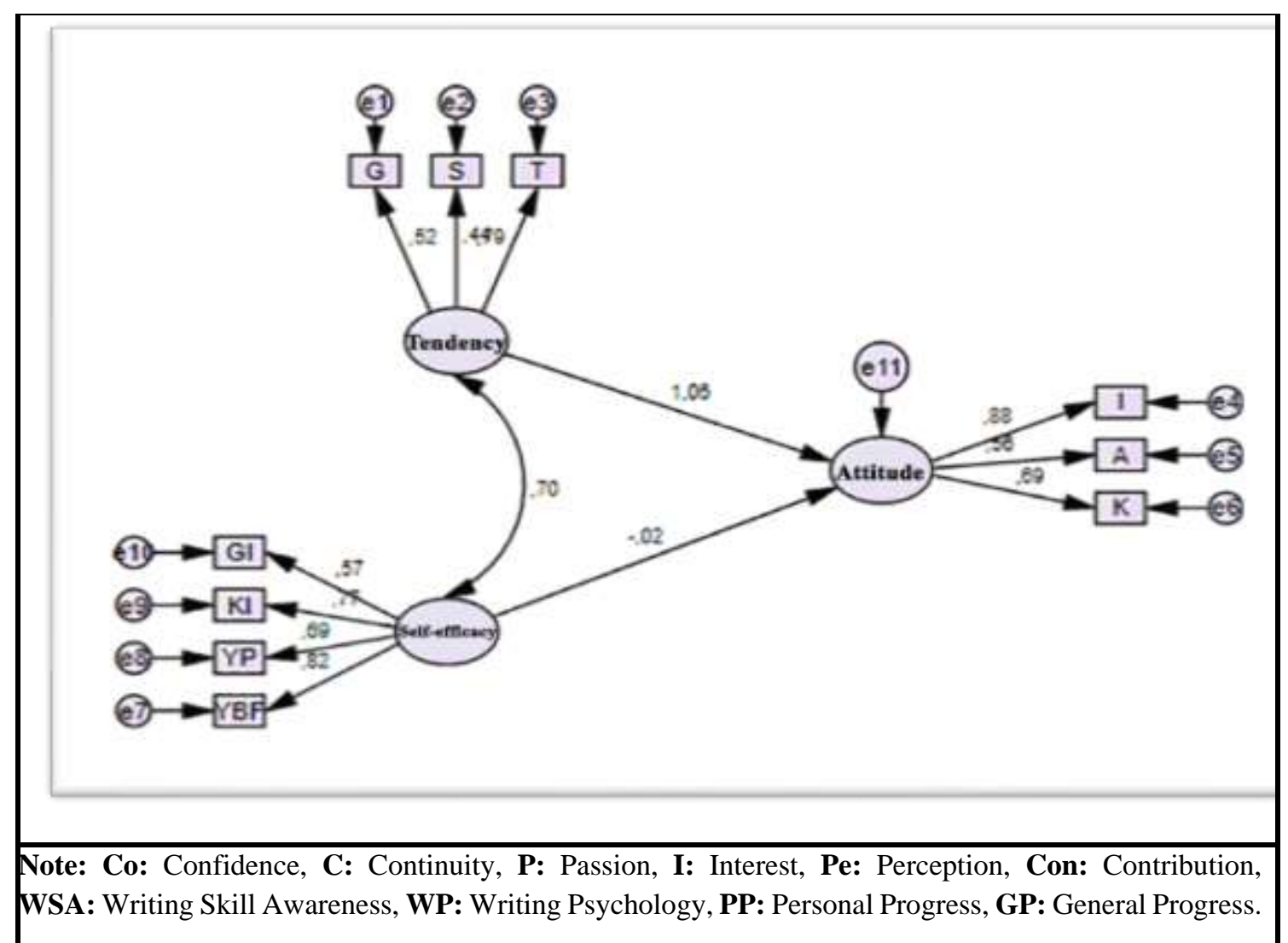

Figure 5. Track diagram for predicting writing attitudes

The goodness of fit achieved through the structural equation modeling, which is established to determine the effect of writing tendency and self-efficacy on writing attitudes was $\chi 2: 4.14$, sd: 32 , RMSEA: 0.07, CFI: 0.89, GFI: 0.88, AGFI: 0,80. According to these results, it can be said that the obtained values are at an acceptable level. As a result of the testing of the structural model, the factor loads of the writing tendency variable were found to be between 0.57 and 0.82 , the factor loads of the writing self-efficacy variable were found to be between 0.57 and 0.82 , and the factor loads of the writing attitude variable were found to be between 0.56 and 0.88 . The standardized regression coefficients of the structural model are presented in Table 2.

Table 2. Standardized regression results on the effect of writing tendency and self-efficacy on writing behavior

\begin{tabular}{|c|c|c|c|c|c|}
\hline Track & $\begin{array}{c}\text { Track } \\
\text { coefficient }(\boldsymbol{\beta}) \\
\end{array}$ & $\begin{array}{c}\text { Standardized } \\
\text { Estimation (Estimate) }\end{array}$ & $\begin{array}{c}\text { Standard } \\
\text { Error (SE) }\end{array}$ & $\begin{array}{c}\text { Critical } \\
\text { Ratio }(\mathbf{C R})\end{array}$ & $\begin{array}{l}\text { Significance } \\
\text { Value (p) }\end{array}$ \\
\hline $\begin{array}{lr}\text { Writing } \\
\text { tendency }\end{array} \quad \longrightarrow \begin{array}{l}\text { Writing } \\
\text { Attitude }\end{array}$ & 1.06 & 3.11 & 0.50 & 6.22 & $* * *$ \\
\hline $\begin{array}{l}\text { Writing Self- } \\
\text { efficacy }\end{array} \stackrel{\text { Writing }}{\longrightarrow \text { Attitude }}$ & 0.02 & -0.02 & 0.12 & -0.15 & 0.87 \\
\hline
\end{tabular}

In Table 2, it was determined that writing attitude was predicted by writing tendency positively and significantly $(\beta: 1.06, \mathrm{p}<0.01)$ and these results were statistically significant $(\mathrm{p}<0.01)$. According to this "H1: Writing tendency positively and significantly predicts writing" hypothesis was accepted. It was found that the writing attitude was positively but not significantly influenced by the writing selfefficacy $(\beta: 0.02, p<0.05)$ and that this result was not statistically significant $(p>.005)$. According to 
this "H2: Writing self-efficacy positively and significantly predicts writing attitudes" hypothesis was rejected.

The Results section presents the study's findings. Results should be clear and concise.

It includes numbers, tables, and figures (e.g., charts and graphs). The information presented and conveyed to the reader in this section should be written objectively, factually, and without expressing personal opinion. For example, you should not make statements such as, "We were disappointed to see that more female participants opted to use computers than male participants as we are often accustomed to seeing male students play computer games."

A good way to organize and discuss your research findings is to restate the hypotheses - research questions, one by one, and present the data collected to test each of them. It is your decision as to what data to present in a narrative form and what to present in tables or figures. Very often, the tables and figures are accompanied by a narrative explanation. You do not need to describe in words everything presented in a numerical or visual form. Instead, take the reader through the numerical and visual information. As the author, you should highlight the main findings, point to trends and patterns, and guide the reader through the information you present. For example, in a table displaying results from four independent-samples $\mathrm{t}$ tests, you can state that the second $\mathrm{t}$ value, which was used to test the second research hypothesis, was statistically significant at $p<.01$, and that the mean of the experimental group was eight points higher than the mean of the control group. You do not need to repeat in the narrative all the numerical information reported in the tables. Or, suppose your Results chapter includes a doublebar graph that is used to show trends and differences in the percentages of male and female teachers in preschool, elementary school, and high school. You may explain that the trend is for the percentage of male teachers to increase with grade level, whereas the percentage of female teachers decreases from preschool to high school.

Number tables consecutively in accordance with their appearance in the text. Place footnotes to tables below the table body and indicate them with superscript lowercase letters. Avoid vertical rules. Be sparing in the use of tables and ensure that the data presented in tables do not duplicate results described elsewhere in the article.

\section{Discussion and conclusions}

In this study, the relationship between writing tendencies and writing self-efficacy levels of secondary school students and the relationship between these variables were examined through structural equation modeling. As a result of the research, the model established for the related literature was tested.

The first hypothesis of the study was proved. Accordingly, it was found that students' writing disposition affects their writing attitude in a significantly positive way. Since both concepts are positive, it is only expected that they affect each other in a positive manner. Confidence and persistence, two of the writing disposition constructs, had a moderate positive impact on writing attitude while attitude towards writing had a positive, high impact on writing disposition. In parallel with the findings of the present study, Baştuğ (2015), Knudson (1995) and Lee (2013) reported that writing disposition affects writing attitude significantly. Kirmızı (2009) found that students with low writing attitude did not want to write. There are also studies indicating that the positive high relationship between writing attitude and writing disposition improves academic performance (McClenny, 2010; Tüfekçioğlu, 2010). Akaydın and Kurnaz (2015) emphasize that there is a close relationship between positive attitude toward writing and engagement in writing activities happily. Those who have positive attitude toward writing are more 
successful than those with negative attitude since the former engage in writing more (Graham, Berninger and Fan, 2007, p. 518).

On the other hand, second hypothesis of the study was not proven. According to the results of the study, students' writing self-efficacy did not have a significant impact on their writing attitude. Although writing self-efficacy affected writing attitude of students in a positive way, no significant relationship was found between the two concepts. Despite the existence of a positive relationship between awareness of writing skills, writing psychology, personal development and overall development, and writing attitude, it was a weak relationship. An analysis of the relevant literature demonstrated no other study that investigated the relationship between writing self-efficacy and writing attitude. However, McCarthy, Meier and Rinderer (1985) as well as Schunk and Swartz (1993) maintained that writing selfefficacy has a positive impact on writing achievement.

In the light of these results, the following suggestions can be made:

- The relationship between other language skills and self-efficacy, tendency and attitude can be examined.

- Qualitative research can be carried out involving Turkish teachers and / or prospective Turkish teachers.

\section{References}

Akaydın, Ş., \& Kurnaz, H. (2015). Lise öğrencilerine yönelik yazma tutum ölçeği: Geçerlilik ve güvenirlik çalışması. Mustafa Kemal University Journal of Social Sciences Institute, 12(32), 246261.

Almerico, G., Johnston, P., Henriott, D., \& Shapiro, M. (2011). Dispositions assessment in teacher education: developing an assessment instrument for the college classroom and the field. Research in Higher Education Journal, 11, 1-19.

Bandura, A. (1982). Self-efficacy mechanism in human agency. American Psychologist, 37(2), 122147.

Baş, G., \& Şahin, C. (2012). İlköğretim öğrencilerinin okuma tutumları, yazma eğilimleri ile Türkçe dersindeki akademik başarıları arasındaki ilişki. Turkish Studies, 7(3), 555-572.

Baş, G., \& Şahin, C. (2013). İlköğretim öğrencilerinin yazma eğilimlerinin farklı değişkenler açısından incelenmesi. Sakarya University Journal of Education, 3(1), 32-42.

Baştuğ, M. (2015). İlkokul dördüncü sınıf öğrencilerinin yazma eğilimi, tutumu ve yazma tutukluğunun yazma başarısı üzerine etkisi. Education and Science, 40(180), 73-88.

Berk, R. R., \& Ünal, E. (2017). Comparison of writing anxiety and writing dispositions of sixth, seventh and eighth grade students. International Journal of Instruction, 10(1), 237-254.

Bruning, R., \& Horn, C. (2000). Developing motivation to write. Educational Psychologist, 35(1), 2537.

Buss, D. M., \& Craik, K. H. (1983). The act frequency approach to personality. Psychological Review, 84, 105-126.

Büyükikiz, K. K. (2012). Türkçeyi ikinci dil olarak öğrenen yabancılar için yazma becerisi öz yeterlilik ölçeğinin geliştirilmesi: geçerlilik ve güvenilirlik çalışması. Mustafa Kemal University Journal of Social Sciences Institute, 9(12), 69-80.

Büyüköztürk, Ş. (2006). Veri analizi el kitabı. Ankara: Pegem A. 
Can, E., \& Topçuoğlu Ünal, F. (2017). Ortaokul öğrencilerine yönelik yazma tutum ölçeği: Geçerlik ve güvenirlik çalışması. International Journal of Languages' Education and Teaching, 5(3), 203212.

Çelik, H. E., \& Y1lmaz, V. (2013). Lisrel 9.1 ile yapısal eşitlik modellemesi temel kavramlaruygulamalar-programlama. Ankara: An1.

Defazio, J., Jones, J., Tennant, F., \& Hook, S. A. (2010). Academicliteracy: The importance and impact of writing across the curriculum - a case study. Journal of the Scholarship of Teaching and Learning, 10(2), 34-47.

Demir, T. (2013). İlköğretim öğrencilerinin yaratıcı yazma becerileri ile yazma özyeterlik algısı ilişkisi üzerine bir çalışma. International Journal of Turkish Literatüre Culture Education, 2(1), 84-114.

Demir, T. (2014). Yazma öz yeterlik ölçeğinin Türkçe formunun geçerlik ve güvenirlik çalışması. $e$ Journal of Educational Researches, 1(2), 28-35.

Demirel, Ö. (1999). İlköğretim okullarında Türkçe öğretimi. İstanbul: Millî Eğitim Bakanlı̆̆ı.

Gemalmaz, E. (2010). Türkçenin derin yapıst. Ankara: Belen.

Göçer, A. (2016). Yazma eğitimi dersinin Türkçe öğretmeni adaylarının yazmaya karş1 tutumlarına etkisi. Kahramanmaraş Sütçü İmam Üniversitesi Sosyal Bilimler Dergisi, 13(2), 343-352.

Graham, S., Berninger, V., \& Fan, W. (2007). The structural relationship between writing attitude and writing achievement in first and third grade students. Contemporary Educational Psychology, 32(3), 516-536.

Güneş, F. (2007). Türkçe öğretimi ve zihinsel yapılandırma. Ankara: Nobel.

Güneş, F., Kuşdemir, Y., \& Bulut, P. (2017). Yazma öz yeterlik ölçeğinin psikometrik özellikleri. The Journal of Academic Social Science Studies, 58, 101-114.

Hidi, S., \& Boscolo, P. (2006). Motivation and writing (Chapter 10). Edt. Macarthur, C., Graham, S. \& Fitzgerald, J., Handbook of Writing Research, New York: The Gullford Press.

Hogg, M. A., \& Vaughan, G. M. (2011). Social psychology (İ. Yıldız \& A. Gelmez, Trans. 4 ed.). Ankara: Ütopya.

İşeri, K., \& Ünal, E. (2010). Yazma eğilimi ölçeği'nin Türkçeye uyarlanması. Education and Science, 35(155), 104-117.

Karagöz, Y. (2016). SPSS ve AMOS 23 uygulamalı istatiksel analizler. Ankara: Nobel.

Karasar, N. (2012). Bilimsel araştırma yöntemi. (24. Basım). Ankara: Nobelç

Karatay, H. (2011). Süreç temelli yazma modelleri: Planl yazma ve değerlendirme. Ankara: Pegem A.

Katz, L. G. (1993). Dispositions: Definitions and implications for early childhood practices. ERIC veri tabanından erişildi. http://files.eric.ed.gov/fulltext/ED360104.pdf adresinden 23.01.2019.

Kırmızı, F. S. (2009). Türkçe dersinde yaratıcı drama yöntemine dayalı yaratıcı yazma çalışmalarının yazmaya yönelik tutuma etkisi. Creative Drama Journal, 4(7), 51-67.

Knudson, R. E. (1995). Writing experiences, attitudes, and achievement of first to sixth graders. Journal of Educational Research, 89(2), 90-97.

Lee, J. (2013). Can writing attitudes and learning behavior overcome gender difference in writing? Evidence from NAEP. Written Communication, 30(2), 164-193.

McCarthy, P., Meier, S., \& Rinderer, R. (1985). Self-efficacy and writing: A different view of selfevaluation. College Composition and Communication, 36, 465-471. 
McClenny, C. S. (2010). A disposition to write: Relationships with writing performance. Yayınlanmamış doktora tezi. Florida State University Libraries.

Özgüven, İ. E. (1994). Psikolojik Testler. Ankara: PDREM.

Pajares, F. (2007). Empirical properties of a scaie to assess writing self-efficacy in schooi contexts, Measurement and Evaluation in Counseling and Development, 39, 239-249.

Pajares, F., Hartley, J., \& Valiante, G. (2001). Response format in writing self - efficacy assessment: greater discrimination increases predicction, Measurement and Evaluation in Counseling and Development, 33, 214-221.

Piazza, C. L., \& Siebert, C. F. (2008). Development and validation of a writing dispositions scale for elementary and middle school students. The Journal of Educational Research, 101(5), 275-285.

Şahin, N. (2012). Maniheist ve Budist ;Uygur şiirinin dilin dört temel becerisi açısından incelenmesi. Yayınlanmamış yüksek lisans tezi. Atatürk University, Institute of Educational Sciences, Erzurum.

Schultz, K., \& Fecho, B. (2000). Society's child: social context and writing development. Educational Psychologist, 35(1), 51-62.

Schunk, D. H., \& Swartz, C. W. (1993). Writing strategy instruction with gifted students: Effects of goals and feedback on self-efficacy. Roeper Review, 15(4), 225.

Şengül, M. (2013). Ortaokul öğrencilerine yönelik “yazma öz yeterlikleri ölçeği” geliştirme çalışması. Turkey Social Studies Journal, 17(1), 81-94.

Silah, M. (2000). Sosyal psikoloji (Davranış Bilimi). Ankara: Gazi.

Snyder, C. R., \& Lopez, S. (2002). Handbook of positive psychology. New York, NY: Oxford University Press.

Sözer, E. (1996). Üniversitelerde öğretim gören öğretmen adaylarının öğretmenlik mesleğine yönelik tutumlar1. Anadolu University Faculty of Education Journal, 6(2), 7-21.

Susar Kırmızı, F., \& Beydemir, F. (2012). İlköğretim 5. sınıf Türkçe dersinde yaratıcı yazma yaklaşımının yazmaya yönelik tutumlara etkisi. Ahi Evran University Kırşehir Education Faculty Journal (KEFAD), 13(3), 319-337.

Susar Kırmızı, F. (2009). Türkçe dersinde yaratıcı drama yöntemine dayalı yaratıcı yazma çalışmalarının yazmaya yönelik tutuma etkisi. Creative Drama Journal, 4(7), 51-68.

Tavşancıl, E. (2010). Tutumların ölçülmesi ve SPSS ile veri analizi. Ankara: Nobel Yayıncılık.

Turkish Language Society. (2011). Türk Dil Kurumu büyük Türkçe sözlük. Ankara: Turkish Language Society .

Uçgun, D. (2014). Altıncı sınıf öğrencilerinin yazma eğilimlerinin incelenmesi. Education and Science, 39(175), 227-238.

White, M. J., \& Bruning, R. (2005). Implicit writing beliefs and their relation to writing quality. Contemporary Educational Psychology, 30, 166-189. 


\section{Ortaokul öğrencilerinin yazma eğilim ve öz yeterliklerinin yazma tutumları üzerindeki etkisi: Bir yapısal eşitlik modellemesi}

\section{$\ddot{O} z$}

$\mathrm{Bu}$ araştırma, ortaokul öğrencilerinin yazma eğilimleri, yazma öz yeterlikleri ve yazma tutumlarının birbirlerini nasıl yordadıklarını tespit etmek amacıyla yapısal eşitlik modellemesi yoluyla yapılmıştır. Bu amaç doğrultusunda tarama modellerinden ilişkisel tarama modeli olarak desenlen araştırma, 2018-2019 eğitim öğretim y1lında Erzurum ilinde 4 farklı ortaokulda öğrenim gören 153’ü (\% 52.8) kı, 137'si (\% 47.2) erkek olmak üzere toplam 290 öğrenciyle yürütülmüştür. Öğrencilerin 20'si 5. sınıf, 30’’u 6. sinıf, 104'ü 7. sınıf ve 122'si 8. sinıf düzeyinde öğrenim görmektedirler. Araştırmada Piazza ve Siebert'in (2008) geliştirdiği, İşeri ve Ünal (2010) tarafından Türkçeye uyarlanan yazma eğilimi ölçeği; Can ve Topçuoğlu Ünal'ın (2017) geliştirdiği yazma tutum ölçeği ve Şengül'ün (2013) geliştirdiği yazma öz yeterlik ölçeği ortaokul öğrencilerine uygulanıp geçerlik ve güvenirlikleri sağlandıktan sonra verilerin analizi yapılmıştır. Araştırma sonucunda yazma eğiliminin yazma tutumunu olumlu etkilediği, yazma öz yeterliklerin yazma tutumunu olumlu etkilemesine rağmen istatistiksel açıdan anlamlı düzeyde etkilemediği belirlenmiştir.

Anahtar Sözcükler: Yazma eğilimi, yazma öz yeterliği, yazma tutumu

\section{AUTHOR BIODATA}

Faruk Polatcan currently an assistant professor in the Department of Turkish and Social Sciences at Sinop University, holds MA and PhD in Turkish Teaching from Atatürk University, Erzurum. His main fields of study are teaching Turkish to foreigners, language teacher education, language learning, teaching language skills, teaching vocabulary.

Nurullah Sahin $(\mathrm{PhD})$ works in the Department of Turkish Education at Ağri Ibrahim Çeçen University, Turkey. He received his BA in the Turkish Education Program at Ataturk University and MA in the Turkish Education Program at Ataturk University in Turkey. He earned his doctoral degree at the University of Ataturk in the Turkey. His research interests include Turkish teaching, reading, listening, speaking, writing and values education. 